\title{
PERENCANAAN PENINGKATAN KUALITAS PRODUK RAKET DENGAN METODE QUALITY FUNCTION DEPLOYMENT
}

\author{
MOH. LUKMAN \\ Jurusan Industri Fakultas Teknik Universitas Muhammadiyah Malang \\ Jl. Raya Tlogomas No.246 Malang \\ E-mai:lukman@umm.ac.id
}

\begin{abstract}
Small Industry Abadi location in central small industry raket Sukun-Malang, so many kinds racket product are many variables as, racket quality, raket colors, rakets price, will give the customer many choice product rackets. Demand racket products are fluctuative from periods to another periods because there are factors: school holiday, and badminton championship in scale national cup and world cup as All England so demand will be increase. In central small industry raket thre are many small industry racket, so competition raket product increase,so there are the price will be cheap and quality may be too lower. This competition cause qoitition in raket " $X$ " is low. Antisipacition to win competition we will design good quality raket product fit with attribute racket customers, with methode Quality Function Deployment (QFD). From result of analysis can know that attribute obtaining especial priority to customer is among others chicken eye of strong plastic type and handle of racket is not breakable, besides technical respon which made account of by company is among others wrap handle of sponge cloth and of racket don't use extension T. Besides got by price for new desain equal to $R p 19.300$,- at the price of selling Rp22.500,- got by cheaper price of Rp1.300,- compared to old desain racket that is equal to Rp20.600,- at the price of selling Rp25.000.
\end{abstract}

Key words: quality, quality function deployment

\section{PENDAHULUAN}

Perusahaan Raket "X" yang berlokasi di sentra industri raket Sukun-Malang merupakan salah satu perusahaan yang memproduksi raket bulutangkis. Dari tahun ke tahun persaingan di bidang industri raket semakin ketat, menyebabkan permintaan produk raket terhadap Perusahaan Raket "X" menjadi berkurang dan produksi raket mengalami penurunan.

Salah satu cara yang bisa dilakukan perusahaan untuk meningkatkan permintaan adalah menghasilkan produk yang dapat memuaskan konsumen. Kepuasan timbul jika konsumen membeli produk yang sesuai dengan selera dan keinginannya, oleh karena itu, perusahaan raket "X" perlu membuat rancangan raket yang baru sehingga permintaannya meningkat dan bersaing dengan perusahaan sejenis. Kualitas menurus Crosby didefinisikan sebagai fitnes for use (Besterfield, 1995) sehingga produk yang berkualitas adalah produk yang sesuai dengan kebutuhan dan keinginan konsumen.
QualityFunctionDeployment(QFD) merupakan metode yang menterjemahkan keinginan konsumen menjadi respons teknis (Cohen, L., 1995) sehingga QFD dapat digunakan sebagai alat untuk pengembangan produk. Tujuan dari penelitian ini adalah untuk merencanakan kualitas produk raket.

\section{METODE}

Diagram alir penelitian dapat dilihat dalam Gambar 1.

Memunculkan atribut-atribut adalah dengan melakukan wawancara kepada beberapa responden yang mewakili konsumen Raket "X". Hasil wawancara ini akan diperlihatkan dalam bentuk Voice of Customer Table (VOCT) dan kemudian dikelompokkan ke dalam diagram affinitas. Data hasil wawancara yang menghasilkan customer phrase dijelaskan ke dalam Voice of Customer Table (VOCT). I dan VOCT II. Selanjutnya data true customer need yang didapat dari VOCT diolah lagi dengan menggunakan diagram afinitas. Langkah- 

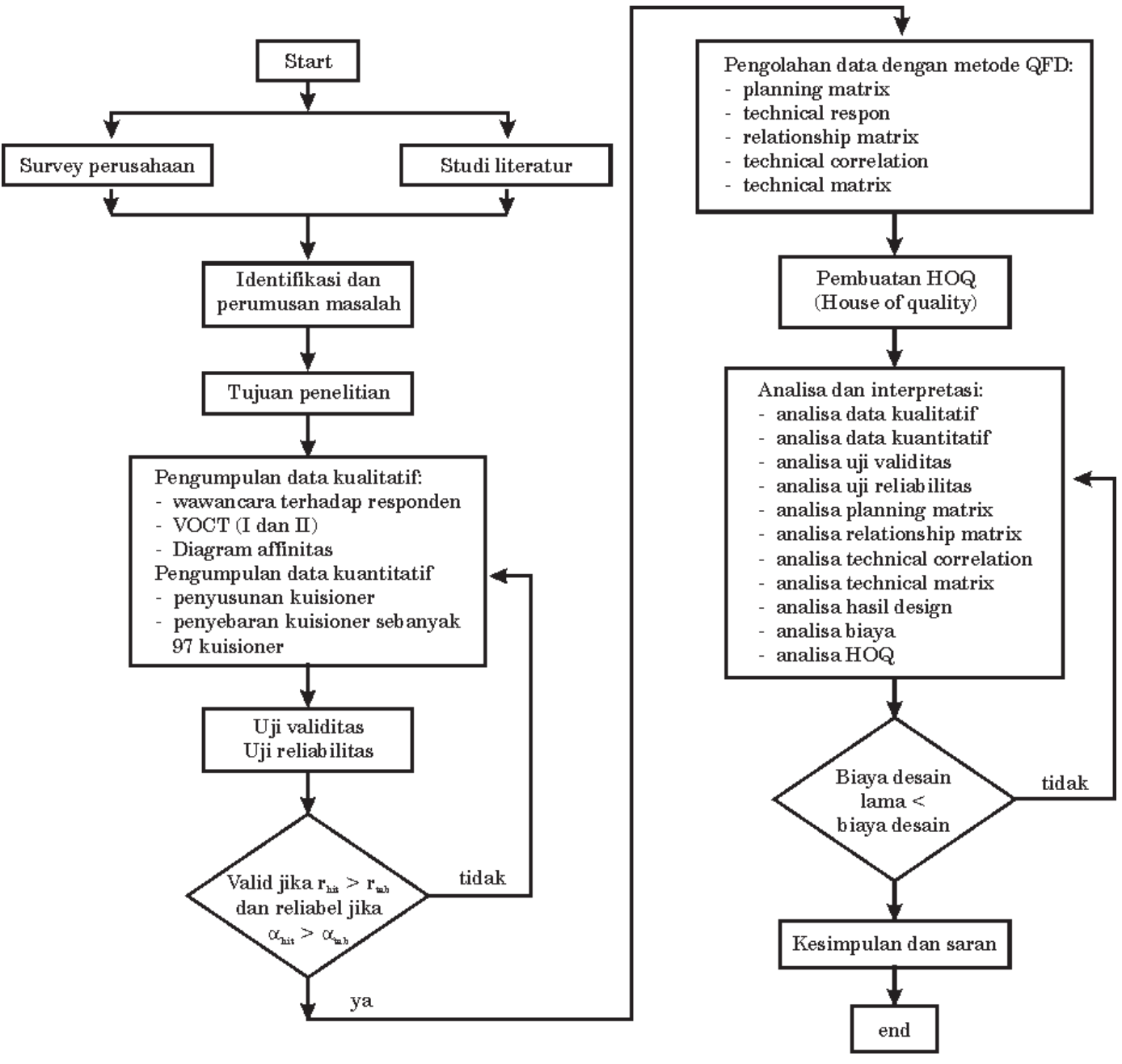

Gambar 1. Diagram alir metode penelitian

langkah penyelesaian diagram afinitas adalah sebagai berikut: mengumpulkan data naratif (true customer need), mentransfer data naratif ke dalam kartu-kartu, menyusun kartu-kartu tersebut ke dalam kelompok yang logis.

Penyusunan kuesioner di sini ada empat kriteria, yaitu untuk lembar kuesioner I (Importance to Customer) untuk mengetahui tingkat kepentingan dari tiap-tiap atribut, lembar kuesioner II (Customer Satisfaction Performance) untuk mengetahui tingkat kepuasan terhadap tiap-tiap atribut, lembar kuesioner III (Sales Point) untuk mengetahui nilai penjualan jika tiap atribut tersebut dipenuhi oleh perusahaan dan lembar kuesioner IV (Competitive Satisfaction Performance) untuk mengetahui tingkat kepuasan terhadap tiap-tiap atribut pada produk pesaing. Penyusunan kuesioner dengan menggunakan Skala Likert 1 sampai 5, yaitu skala yang berisi lima tingkat jawaban.

Penyebaran kuesioner ini dilakukan di wilayah Malang dengan responden para pelanggan produk raket "X" dan juga produk pesaing, yaitu produk raket "Y".

Agar sampel memiliki populasi maka perlu diidentifikasi apakah datanya mencukupi atau tidak. Dalam menentukanjumlah sampel penelitian dilakukan perhitungan dengan rumus Bernoulli sebagai berikut (Arikunto, S., 1998).

$$
\mathrm{N} \geq \frac{\left(\mathrm{Z}_{\alpha / 2}\right)^{2} \mathrm{xp}(1-\mathrm{p})}{\mathrm{e}^{2}}
$$


Apabila proporsi kuesioner dianggap benar 95\% maka nilai kesalahan $=p=5 \%$, nilai $\alpha=$ $1-0,95 \%$ sehingga $Z_{\alpha / 2}=Z_{0,05}=1,96$

$$
\begin{gathered}
\mathrm{N} \geq \frac{(1,96)^{2} \times 0,05(1-0,05)}{(0,05)^{2}} \\
\mathrm{~N} \geq 72,99 \approx 73
\end{gathered}
$$

Maka jumlah kuesioner yang harus disebar minimal sebanyak 73 kuesioner.

Uji validitas digunakan untuk mengetahui apakah pertanyaan-pertanyaan pada kuesioner mampu untuk menggambarkan tiap-tiap atribut yang diinginkan konsumen. Rumus yang digunakan untuk menghitung nilai tiap atribut menggunakan teknik Korelasi Product Moment adalah sebagai berikut (Azwar, S., 1997):

$$
\mathrm{r}_{\mathrm{xy}}=\frac{\mathrm{n}\left(\sum \mathrm{xy}\right)-\left(\sum \mathrm{x} \sum \mathrm{y}\right)}{\sqrt{\left[\mathrm{n} \sum \mathrm{x}^{2}\left(\sum \mathrm{x}\right)^{2}\right]\left[\mathrm{n} \sum \mathrm{y}^{2}\left(\sum \mathrm{y}\right)^{2}\right]}}
$$

Apabila $\mathrm{r}_{\mathrm{xy}}$ hitung $>$ dari $\mathrm{r}_{\text {tabel }}$, maka data tersebut dikatakan valid, atau suatu kuesioner tersebut mampu menggambarkan terhadap atribut yang diinginkan konsumen.

Uji keandalan (reliability) digunakan untuk melihat tingkat konsistensi dari konsumen., koefisien korelasi dihitung sebagai berikut:

$$
\mathrm{r}_{\mathrm{tt}}=\left(\frac{\mathrm{k}}{\mathrm{k}-1}\right)\left(1-\frac{\sum \sigma^{2} \mathrm{~b}}{\sigma_{\mathrm{t}}^{2}}\right)
$$

Data dikatakan reliabel jika nilai Cronbach Alpha $>0,60$. Uji validitas dan uji reliabilitas data menggunakan software windows SPSS 12.0 for windows (Sugiona dan Wibowo E., 2001).

Tahap pengolahan data dengan Metode QFD meliputi: (1) Planning Matrix; Pembentukan kualitas dimulai dengan mengklasifikasi data dalam matriks perencanaan yag digunakan untuk mengetahui atribut mana yang akan dikembangkan terlebih dahulu berdasarkan kontribusinya dalam memenuhi kebutuhan konsumen yang terdiri atas 7 tipe data yang berbeda, yaitu: importance to customer, customer satisfaction perfomance, competitive satisfaction perfomance, goal, improvement ratio, sales point, raw weight dan normalized raw weight. (2) Technical Respons; Respons teknis adalah spesifikasi teknis yang dimunculkan oleh tim pengembang kualitas berdasarkan urutan-urutan proses produksi, bahan serta mesin yang digunakan untuk memenuhi kebutuhan atau keinginan konsumen. (3) Relationship Matrix; Matriks ini menunjukkan hubungan antara kebutuhan konsumen dengan respons teknis yang digunakan dalam bentuk simbol-simbol hubungan kuat, menengah dan lemah. (4) Technical Correlation; Matriks yang menggambarkan hubungan gambaran antar respons teknis yang juga ditunjukkan dengan simbol-simbol tertentu. (5) Technical Matrix; Matriks ini digunakan untuk mengetahui prioritas respons teknis yang dapat memenuhi kebutuhan konsumen, competitive benchmarking dan menentukan target respons teknis yang akan ditingkatkan melalui analisis perbandingan dengan produk pesaing. (6) Pembuatan House of Quality (HOQ); Setelah dilakukan pengolahan data dengan konsep QFD, yaitu mulai dari Planing Matrix, Technical Respons, Relationship Matrix, Technical Correlation dan Technical Matrix, maka langkah selanjutnya adalah menyusun dalam bentuk sebuah rumah kualitas.

\section{HASIL DAN PEMBAHASAN}

Voice of Customer Table adalah tabel berfungsi untuk menjelaskan akan kebutuhan dan keinginan pelanggan yang diperoleh dari hasil wawancara pelanggan. Customer Needs tersebut kemudian diperjelas ke dalam Voice of Customer Table bagian I (VOCT I) dengan rumus $4 \mathrm{~W}+1 \mathrm{H}$. Dari hasil VOCT I kemudian diolah lebih dalam pada VOCT II di mana customer phrase ditempatkan dalam satu list yang meliputi kolom customer need, function, reliability, dan target value dan SQC. Pada VOCT II didapat atribut sebanyak 25 atribut.

Berdasarkan data Voice of Customer Table I dan II, kemudian dilakukan pengelompokan untuk menentukan atribut yang tergolong true customer need dengan menggunakan diagram afinitas. Berdasarkan hasil pengelompokan didapat 25 atribut ke dalam 9 kelompok di antaranya untuk handle dan bungkus handle raket sebanyak 4 atribut, warna raket sebanyak 2 atribut, senar raket sebanyak 4 atribut, kemasan sebanyak 2 atribut, 


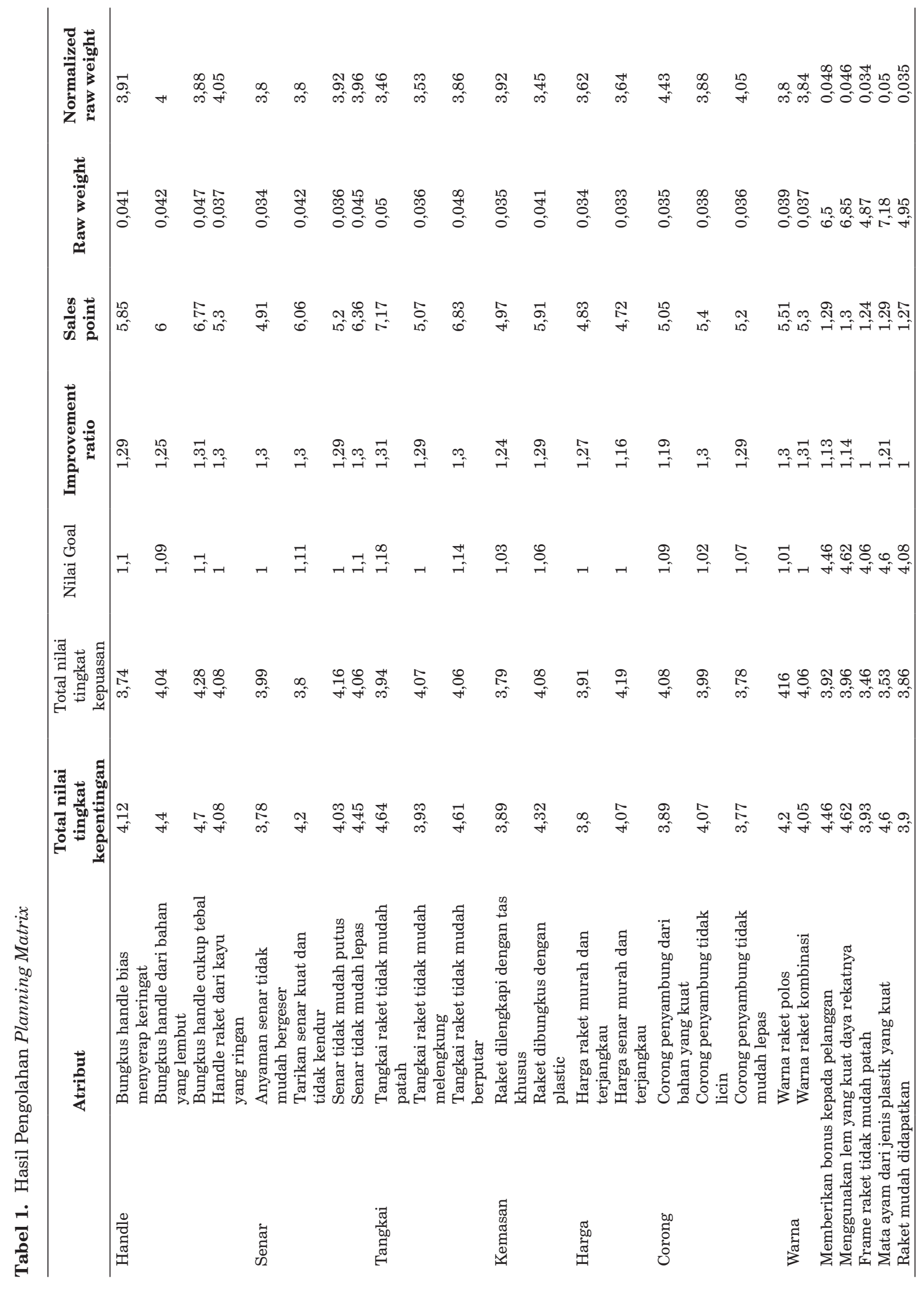


harga sebanyak 2 atribut, tangkai/batang raket sebanyak 3 atribut, corong penyambung sebanyak 3 atribut, lem raket ada 1 atribut, jenis mata ayam raket ada 1 atribut, bonus kepada pelanggan ada 1 atribut, frame raket ada 1 atribut dan penjualan raket ada 1 atribut.

Penyebaran kuesioner dilakukan di wilayah Malang dengan responden para pengguna produk raket. Kuesioner awal disebarkan sebanyak 30 kuesioner dan untuk kuesioner akhir sebanyak 67 kuesioner. Pengujian data dilakukan pada data hasil penyebaran kuesioner, pengujian yang dilakukan adalah uji validitas dan reliabilitas. Pengujian validitas dan reliabilitas dengan menggunakan software SPSS 12.00 for Windows. Pengujian validitas dan reliabilitas untuk data sebanyak 97 sampel, apabila semua atribut bisa dikatakan valid dan reliabel, maka kuesioner tersebut bisa diterima atau layak untuk diterapkan.

Dari kuesioner hasil perhitungan untuk semua atribut, maka diperoleh semua nilai $r_{\text {hitung }}$ lebih besar dari $r_{\text {tabel }}$ (semua nilai $r_{\text {hitung }}>0,1313$ ) sehingga semua atribut untuk kuesioner importance to customer, customer satisfaction performance, sales point dan competitive satisfaction performance dikatakan valid atau suatu kuesioner tersebut mampu menggambarkan atribut yang diinginkan konsumen.

Dalam penelitian ini pengujian reliabilitas menggunakan Rumus Cronbach Alpha. Data dikatakan reliabel jika nilai Cronbach Alpha lebih besar dari (Santoso, 2001). Berdasarkan hasil perhitungan untuk semua kuesioner, maka diperoleh nilai Cronbach Alpha lebih besar dari 0,60 baik untuk data 30 kuesioner atau 67 kuesioner sehingga data untuk kuesioner importance to customer, customer satisfaction performance dan competitive satisfaction dikatakan reliabel atau jawaban responden tersebut konsisten.

Matriks perencanaan bertujuan untuk menentukan atribut mana yang harus dikembangkan atau ditingkatkan terlebih dahulu oleh tim pengembang kualitas produk, sebanyak 97 responden yang mengisi kuesioner dengan menghitung rata-rata setiap item pertanyaan pada setiap pengumpulan data. Planning matrix terdiri atas 7 data yang berbeda, yaitu: importance to customer, customer satisfaction performance, competitif satisfaction performance, goal, improvement ratio, sales point, raw weight dan normalized raw weight.

Importance to customer bertujuan untuk mengetahui tingkat kepentingan tiap-tiap atribut menurut responden. Data importance to customer diperoleh dari hasil penyebaran kuesioner pada lembar kuesioner I (importance to customer), dengan cara menghitung rata-rata tiap item pertanyaan (atribut). Tiga besar nilai importance to customer adalah sebagai berikut 1) Tangkai raket tidak mudah patah 2) Senar tidak mudah lepas 3) Bungkus handle dari bahan yang lembut.

Customer satisfaction performance bertujuan untuk mengetahui tingkat performansi kepuasan terhadap tiap-tiap atribut pada produk raket "X". Data customer satisfaction performance diperoleh dari hasil penyebaran kuesioner pada lembar kuesioner II (customer satisfaction performance), dengan cara menghitung rata-rata tiap item pertanyaan (atribut). (Ashok Rao: 1996). Tiga besar nilai customer satisfaction performance adalah sebagai berikut 1) Corong penyambung dari bahan yang kuat 2) Handle raket dari kayu yang ringan 3) Bungkus handle dari bahan yang lembut.

Competitive satisfaction performance. Competitive satisfaction performance merupakan tingkat kepuasan pelanggan untuk produk raket "Y", sebagai produk raket pesaing. Data untuk competitive satisfaction performance didapat dari kuesioner pada lembar IV, dengan cara menghitung rata-rata tiap item atribut. Tiga Besar nilai competitive satisfaction performance adalah sebagai berikut 1) Tangkai raket tidak mudah patah/melengkung 2) Tangkai raket tidak mudah berputar 3) Senar tidak mudah putus.

Goal adalah suatu level performansi yang ingin dicapai perusahaan dalam memenuhi customer needs, sangat terkait dengan tingkat performansi untuk memenuhi keinginan konsumen. Nilai Goal diperoleh dari perbandingan tertinggi antara nilai tingkat kepentingan konsumen (importance to customer), nilai performansi kepuasan konsumen terhadap produk raket "X" (customer satisfaction performance) dan nilai performansi kepuasan konsumen terhadap produk pesaing yaitu produk raket "Y" (competitive satisfaction performance) (Cohen, 1995). Tiga besar nilai goals adalah sebagai 
berikut 1) Tangkai raket tidak mudah patah 2) Tangkai raket tidak mudah berputar 3) Corong penyambung dari bahan yang kuat.

Nilai improvement ratio didapat dari perbandingan antara goal dan current satisfaction performance. Nilai ini menunjukkan bobot kesulitan untuk melakukan peningkatan dalam memenuhi kebutuhan pelanggan, tiga besar nilai improvement ratio adalah sebagai berikut:1) Mata ayam dari jenis plastik yang kuat 2) Tangkai raket tidak mudah patah 3) Tangkai raket tidak mudah berputar.

Sales point bertujuan untuk mengetahui reaksi dari konsumen apabila kebutuhannya dapat dipenuhi oleh perusahaan tersebut. Sales point adalah merupakan informasi mengenai kemampan menjual produk berdasarkan seberapa baik setiap customer need terpenuhi. Tiga besar nilai sales point antara lain: 1) Handle raket dari kayu yang ringan 2) Anyaman senar tidak mudah bergeser 3) Tarikan senar kuat dan tidak kendur.

Raw weight dan normalized raw weight bertujuan untuk mengetahui pembobotan untuk atribut mana yang memiliki nilai tertinggi sehingga akan menjadi perhatian utama perusahaan untuk ditingkatkan dalam memenuhi kepuasan pelanggan dengan urutan tiga besar: 1) Mata ayam dari jenis plastik yang kuat 2) Tangkai raket tidak mudah patah 3) Tangkai raket tidak mudah berputar.

Relationship matrix menunjukkan hubungan antara keinginan pelanggan (customer needs) dengan respons teknis. Relationship matrix dapat diketahui sejauh mana respons teknis yang diberikan untuk meningkatkan kepuasan pelanggan terhadap atribut-atribut yang ada. Untuk menentukan hubungan antara kebutuhan pelanggan dengan respon teknis ini dilakukan oleh pihak peneliti dengan bantuan pihak perusahaan. Hubungan yang terjadi dapat digambarkan dengan menggunakan simbol (Cohen, 1995) sebagaimana tertera pada Tabel 2 .

Tabel 2. Simbol Relationships Matrix

\begin{tabular}{ccl}
\hline Simbol & Nilai & \multicolumn{1}{c}{ Pengertian } \\
\hline$<$ kosong $>$ & 0 & Tidak ada hubungan \\
$\Delta$ & 1 & Mungkin ada hubungan \\
$\bigcirc$ & 3 & Hubungan sedang \\
$\bigcirc$ & 9 & Sangat kuat hubungannya \\
\hline
\end{tabular}

Technical correlation digunakan untuk mengidentifikasi hubungan antara masing-masing technical response. Hubungan ini digambarkan dengan simbol-simbol sebagaimana tertera pada Tabel 3.

Tabel 3. Simbol Technical Correlation

\begin{tabular}{cl}
\hline Simbol & \multicolumn{1}{c}{ Pengertian } \\
\hline++ & Pengaruh positif sangat kuat \\
+ & Pengaruh positif cukup kuat \\
$<$ kosong $>$ & Tidak ada pengaruh \\
- & Pengaruh negatif cukup kuat \\
-- & Pengaruh negatif sangat kuat \\
\hline
\end{tabular}

Technical matrix bertujuan menentukan respons teknis mana yang ingin dikonsentrasikan dan bagaimana jika dibandingkan dengan produk pesaing, matriks ini meliputi Priorities Technical Response, Competitive Benchmarks, GAP dan Target.

Priorities technical response dilakukan dengan menghitung terlebih dahulu kontribusi relatif setiap respons teknis terhadap keseluruhan customer satisfaction. Hal ini yang akan menentukan prioritas dari respon teknis perusahaan. Dengan cara perhitungan yang sama maka nilai contribution dan normalized contribution pada respons teknis lainnya dapat dilihat pada Tabel 4 .

Competitive Benchmarking bertujuan untuk memposisikan produk dari perusahaan terhadap produk dari pesaing. Competitive Benchmarking diterapkan untuk menciptakan atau meningkatkan daya saing serta mampu memperbaiki posisi produk dalam pasar yang kompetitif. Hal ini untuk mengetahui nilai Benchmarking dengan menentukan relationship matrix dengan customer satisfaction performance dancompetitivesatisfaction performance. Tiga keunggulan competitive benchmarking produk raket "X" Terhadap pesaing raket "Y":1) Bungkus handle dari kain spon 2) Senar dipasang dengan kekuatan tarik 22-24 pound.

GAP merupakan merupakan tingkat keunggulan dan kelemahan antara produk kita dengan produk pesaing. Nilai GAP diperoleh dari selisih antara produk raket "X" dengan produk raket "Y" pada nilai competitive benchmarking. Tiga kelemahan Gap produk raket "X" terhadap pesaing raket "Y" 1) Menggunakan senar jenis hi-ceef 2) Raket dilengkapi dengan kemasan 
yang menarik 3) Raket tidak menggunakan sambungan $\mathrm{T}$.

Target merupakan suatu tujuan yang ingin dicapai oleh perusahaan untuk respons teknis yang dimilikinya agar respons teknis perusahaan mampu memenuhi customer needs. Dengan menentukan target, perusahaan akan memiliki suatu tujuan yang jelas. Menunjukkan bagaimana respons teknis dicapai dengan meningkatkan atau menurunkan sesuai dengan perkembangan yang diinginkan untuk menunjukkan target perusahaan tersebut. Dalam menentukan target ini peneliti meminta pertimbangan ke pemilik perusahaan, dan karyawan dengan menggunakan simbol: $\uparrow$ Menyatakan semakin ditingkatkan semakin baik. $\downarrow$ Menyatakan semakin diturunkan semakin baik.
O Menyatakan solusi yang ditentukan adalah sudah baik.

Berdasarkan hasil pembuatan rumah kualitas dapat diketahui bahwa atribut yang memiliki nilai bobot tertinggi yang didapat dari prioritas respon teknis berdasarkan nilai pada contribution harus dipenuhi oleh perusahaan. Selain itu pada HOQ juga dilengkapi dengan target karakteristik teknis berdasarkan prioritas respons teknis. Target karakteristik teknis tersebut merupakan penjabaran dari respons teknis yang diupayakan oleh pihak perusahaan. Dari atribut yang dipentingkan oleh konsumen dan prioritas respons teknis maka menjadi dasar dalam perencanaan dan perbaikan pada desain usulan produk raket "X" yang diupayakan oleh pihak perusahaan raket

Tabel 4. Technical Matrix

\begin{tabular}{|c|c|c|c|c|c|c|}
\hline \multirow{2}{*}{ Respons teknis } & \multicolumn{2}{|c|}{ Nilai contributions } & \multicolumn{2}{|c|}{ Nilai BenchMark } & \multirow{2}{*}{ GAP } & \multirow{2}{*}{ Target } \\
\hline & Contributions & Normalized & Raket "X" & Raket "Y" & & \\
\hline $\begin{array}{l}\text { Pemasangan senar tidak kendur } \\
\text { Senar dipasang dengan }\end{array}$ & 0,732 & 0,053 & 10,851 & 10,953 & $-0,102$ & $\uparrow$ \\
\hline kekuatan tarik $22-24$ pound & 0,572 & 0,042 & 16,191 & 15,519 & 0,672 & $\uparrow$ \\
\hline Handle raket dari kayu waru & 0,72 & 0,052 & 9,234 & 8,064 & 1,17 & $\uparrow$ \\
\hline $\begin{array}{l}\text { Raket dibuat dengan banyak } \\
\text { pilihan warna }\end{array}$ & 0,672 & 0,049 & 8,673 & 8,933 & $-0,26$ & $\uparrow$ \\
\hline $\begin{array}{l}\text { Tangkai raket diproses dengan } \\
\text { carborising }\end{array}$ & 0,791 & 0,057 & 9,33 & 9,624 & $-0,294$ & $\uparrow$ \\
\hline $\begin{array}{l}\text { Harga senar raket Rp } 10.000,- \\
\text { /bks }\end{array}$ & 0,657 & 0,048 & 4,219 & 5,065 & $-0,846$ & $\mathrm{O}$ \\
\hline Bungkus handle dari kain spon & 1,926 & 0,14 & 23,085 & 21,357 & 1,728 & O \\
\hline $\begin{array}{l}\text { Raket dilengkapi dengan } \\
\text { kemasan yang menarik }\end{array}$ & 0,644 & 0,047 & 5,354 & 8,788 & $-3,434$ & $\mathrm{O}$ \\
\hline $\begin{array}{l}\text { Raket ringan dengan berat } \pm \\
79 \text { gr }\end{array}$ & 0,365 & 0,027 & 5,259 & 4,431 & 0,828 & $\uparrow$ \\
\hline $\begin{array}{l}\text { Raket tidak menggunakan } \\
\text { sambungan T }\end{array}$ & 0,972 & 0,071 & 2,886 & 4,092 & $-1,206$ & $\uparrow$ \\
\hline Lokasi penjualan strategis & 0,108 & 0,008 & 4,563 & 4,287 & 0,276 & O \\
\hline $\begin{array}{l}\text { Lem yang digunakan adalah lem } \\
\text { epoxy }\end{array}$ & 0,642 & 0,047 & 7,695 & 7,119 & 0,576 & $\mathrm{O}$ \\
\hline Corong penyambung dari besi & 0,432 & 0,031 & 2,727 & 1,644 & 1,083 & $\uparrow$ \\
\hline $\begin{array}{l}\text { Mata ayam dari plastik jenis } \\
\text { PPC }\end{array}$ & 0,501 & 0,036 & 6,126 & 4,908 & 1,218 & $\uparrow$ \\
\hline $\begin{array}{l}\text { Layanan purna jual berupa } \\
\text { garansi dan servis }\end{array}$ & 0,501 & 0,036 & 6,126 & 4,908 & 1,218 & $\mathrm{O}$ \\
\hline $\begin{array}{l}\text { Batang/tangkai raket kuat dan } \\
\text { lentur }\end{array}$ & 0,642 & 0,047 & 7,695 & 7,119 & 0,576 & $\uparrow$ \\
\hline $\begin{array}{l}\text { Harga raket berkisar antara } R p \\
20.000,- \text { s/d Rp } 35.000,-\end{array}$ & 0,969 & 0,07 & 6,135 & 7,074 & $-0,939$ & $\uparrow$ \\
\hline $\begin{array}{l}\text { Bonus berupa perlengkapan } \\
\text { raket }\end{array}$ & 0,765 & 0,056 & 8,37 & 8,73 & $-0,36$ & $\uparrow$ \\
\hline $\begin{array}{l}\text { Frame raket dari bahan } \\
\text { aluminium }\end{array}$ & 0,51 & 0,037 & 3,721 & 3,853 & $-0,132$ & $\uparrow$ \\
\hline $\begin{array}{l}\text { Menggunakan senar jenis hi- } \\
\text { ceef }\end{array}$ & 0,644 & 0,047 & 5,354 & 8,788 & $-3,434$ & 0 \\
\hline
\end{tabular}


"X" berdasarkan pertimbangan sumber daya perusahaan dan kepentingan konsumen.

\section{SIMPULAN}

Atribut yang diprioritaskan untuk dikembangkan terlebih dahulu oleh Pengusaha kecil raket "X", sesuai dengan atribut yang diinginkan konsumen antara lain: mata ayam dari jenis plastik yang kuat, tangkai raket tidak mudah patah, menggunakan lem yang kuat daya rekatnya, tangkai raket tidak mudah berputar, bungkus handle cukup Tabel 1.

Respons teknis yang harus dilakukan pengusaha kecil raket "X" untuk antisipasi atribut yang diinginkan cutomer: bungkus handle dari kain spon, raket tidak menggunakan sambungan $\mathrm{T}$, harga raket berkisar antara Rp20.000,- s/d Rp35.000,tangkai raket diproses dengan carborising, bonus berupa perlengkapan raket, pemasangan senar tidak kendur, handle raket dari kayu waru.

\section{DAFTAR PUSTAKA}

Arikunto, S., 1998. Prosedur Penelitian: Suatu Pendekatan Praktek, Edisi Revisi IV. Jakarta: PT Rineka Cipta.

Azwar, S., 1997. Reliabilitas dan Validitas. Edisi 3, Yogyakarta: Pustaka Pelajar Offset.

Besterfield D., Michna, C.B., Glen B., Mary's Besterfield Sacre, 1995. Total Quality Management, Prentice Hall.

Cohen, L., 1995. QFD, How to Make QFD Work for You, Addison Wesley Publishing Co.

Gasperrsz, V., 2002. Total Quality Management, Jakarta: Gramedia Pustaka Utama.

Ibrahim, B., 2002. TQM: Panduan untuk Menghadapi Persaingan Global, Penerbit Djambatan.

Sugiyono dan Wibowo, E., 2001. Statistika Penelitian dan Aplikasinya dengan SPSS 10.0 for Windows. Bandung: Alfabeta.

Santoso S., 2001. SPSS Statistik Parametrik, Jakarta: Gramedia,.

Tjiptono, F. dan Diana, 1996. A Total Quality Management, Yogyakarta: Penerbit Andi Offset. 